\title{
Detection of mutations in the rpoB gene of rifampicin-resistant Mycobacterium tuberculosis strains inhibiting wild type probe hybridization in the MTBDR plus assay by DNA sequencing directly from clinical specimens
}

Pallavi Sinha ${ }^{1}$, G. N. Srivastava ${ }^{2^{*}}$, Rajneesh Tripathi ${ }^{1}$, Mukti Nath Mishra ${ }^{3}$ and Shampa Anupurba ${ }^{1 *}$

\begin{abstract}
Background: The potential of genetic testing for rapid and accurate diagnosis of drug-resistant Mycobacterium tuberculosis strains is vital for efficient treatment and reduction in dissemination. MTBDR plus assays rapidly detect mutations related to drug resistance and wild type sequences allied with susceptibility. Although these methods are promising, the examination of molecular level performance is essential for improved assay result interpretation and continued diagnostic development. Therefore this study aimed to determine novel mutations that were inhibiting wild type probe hybridization in the Line probe assay by DNA sequencing. Using data collected from Line Probe assay (GenoType MTBDRplus assay) the contribution of absent wild type probe hybridization to the detection of rifampicin resistance was assessed via comparison to a reference standard method i.e. DNA sequencing.

Results: Sequence analysis of the rpoB gene of 47 MTB resistant strains from clinical specimens showed that 37 had a single mutation, 9 had double mutations and one had triple mutations in the ropB gene.

Conclusions: The absence of wild type probe hybridization without mutation probe hybridization was mainly the result of the failure of mutation probe hybridization and the result of the novel or rare mutations. Additional probes are necessary to be included in the Line probe assay to improve the detection of rifampicin-resistant Mycobacterium tuberculosis strains.
\end{abstract}

Keywords: DNA sequencing, Genotype MTBDRplus, Line probe assays, Mycobacterium tuberculosis, Reference standard

\footnotetext{
* Correspondence: gn_sri@yahoo.co.in; shampa_anupurba@yahoo.co.in

${ }^{2}$ Department of Respiratory Diseases, Institute of Medical Sciences, Banaras Hindu University, Varanasi, Uttar Pradesh 221005, India

'Department of Microbiology, Institute of Medical Sciences, Banaras Hindu University, Varanasi 221 005, India

Full list of author information is available at the end of the article
}

(c) The Author(s). 2020 Open Access This article is licensed under a Creative Commons Attribution 4.0 International License, which permits use, sharing, adaptation, distribution and reproduction in any medium or format, as long as you give appropriate credit to the original author(s) and the source, provide a link to the Creative Commons licence, and indicate if changes were made. The images or other third party material in this article are included in the article's Creative Commons. licence, unless indicated otherwise in a credit line to the material. If material is not included in the article's Creative Commons licence and your intended use is not permitted by statutory regulation or exceeds the permitted use, you will need to obtain permission directly from the copyright holder. To view a copy of this licence, visit http://creativecommons.org/licenses/by/4.0/. The Creative Commons Public Domain Dedication waiver (http://creativecommons.org/publicdomain/zero/1.0/) applies to the data made available in this article, unless otherwise stated in a credit line to the data. 


\section{Background}

Tuberculosis (TB), caused by Mycobacterium tuberculosis complex (MTBC), one of the world's lifethreatening communicable diseases and it ranks alongside the human immunodeficiency virus (HIV) as a leading cause of death [1]. The current increase in drugresistant strains due to unsuccessful treatment and increased dissemination of resistance exhibits an important problem for global TB control efforts [2]. The diagnosis of tuberculosis depends on strong laboratory examination and skilled and dedicated personnel for treatment inaccuracy and supervision.

Conventional culture-based drug susceptibility testing methods take 4-8 weeks to yields results [3]. During this time, patients may be taking chemotherapeutics that are completely ineffective, and risk instantly transmitting the resistant disease to other persons. Therefore, there is an imperative need for rapid diagnosis of drug-resistant TB strains.

The WHO has endorsed the commercially available Line Probe Assay (LPA), the GenoType MTBDRplus assay (Hain Lifescience, Nehren, Germany) [4, 5]. The GenoType MTBDRplus assay detects the presence of $M$. tuberculosis together with the most common genetic mutations that conferring resistance to rifampicin (RIF) (mutations within the $r p o B$ gene) and isoniazid (INH) (mutations within the katG gene and the inhA promoter), [6-8] and its diagnostic presentation has been evaluated in smear-positive pulmonary samples [6]. The diagnosis by the MTBDRplus assay depends on the amplification of gene regions known to bear resistance-associated mutations, as intent by reverse hybridization to wild-type (wt) and mutated sequences.

Rifampicin is one of the most potent first-line anti-TB drug that serves as a surrogate marker for the detection of multidrug resistant-tuberculosis (MDR-TB), as $>90 \%$ of Rif $^{r}$ isolates are also isoniazid-resistant, another potent first-line anti-TB drug [9-11].

MTBDRplus assay has certain limitations in that MTB strains could have uncommon mutations. Few studies have reported that MTB strains have uncommon mutations in the $r p o B$ gene [12-14]. Thus, it is essential to determine the mutation patterns among a large number of MTB isolates from various parts of India, since this would help not only in the design of a desirable diagnostic method for rapid detection of MDR-TB but also in the identification of any hot-spot regions in the different countries for the proper execution of TB control programs.

The present study aimed to determine novel mutations those were inhibiting WT probe hybridization in the Line Probe assay (Genotype MTBDRplus assay) by DNA sequencing.

\section{Results}

A total of 150 AFB smear-positive pulmonary samples were analyzed using the GenoType MTBDRplus assay. Out of 150 samples, in 35 samples MTB was not detected, 98 samples were RIF resistant, and 17 samples identified as susceptible to RIF. Using the GenoType MTBDRplus assay, corresponding resistance rates were $65.3 \%(98 / 150)$. The most common genetic mutation conferring RIF resistance was Ser531Leu of the $r p o B$ gene, detected in $63.3 \%(62 / 98)$ of RIF resistant strains. The next most frequent $r p o B$ mutation encountered was Asp516Val which was detected in $21.4 \%$ (21/98) RIF resistant strains, followed by His526Tyr $12.2 \%$ (12/98) and combined His526Tyr, Ser531Leu in 3.1\% (3/98) of the tested specimens.

Thirty-one percent (47/150) RIF resistant strains detected from clinical samples had non- interpretable (NI) results that could not be identified by GenoType MTBDRplus assay, missing.

bands on the wild type region of these strains but no hybridization with mutation probes suggested resistance due to mutations other than those included in MTBDRplus assay.

\section{Indeterminate GenoType MTBDRplus assay results for RIF resistant clinical specimens}

Indeterminate results come about alongside for RIF in $31.3 \%(47 / 115)$ of the tests. The patterns of noninterpretable mutations associated with rifampicin resistance MTB strains in 47 samples are shown in Table 1. In 47 RIF resistant strains, one or more wild type probes were missing with no bands in mutant probes (Fig. 1). These 47 strains included missing WT8 (14; 29.8\%), missing WT3\&WT4 (16; 34\%), missing WT2 (4; 8.5\%), missing WT7 (5; 10.6\%), missing WT3 (3; 6.4\%), missing WT1,WT3\&W4 (1; 2.1\%) missing WT5 (1; 2.1\%), missing WT4 $(2 ; 4.2 \%)$ and missing WT5\&WT6 (1; 2.1\%). DNA sequence analysis of the 47 RIF resistant MTB strains from clinical specimens showed that 37 had a single mutation, 9 had double mutations and one had triple mutations in the $r p o B$ gene.

Fifteen different types of missense mutations were identified in 47 rifampicin-resistant strains from those with non-interpretable results at codons 516, 506, 509, 510, 511, 513, 515, 518, 526, 528, 531, 533, 572 and 605. Fifty different missense mutations were caused by single base substitutions $(n=26)$, deletions $(n=1)$ and insertions $(n=3$; Table $1 \&$ Fig. 2$)$. Fifteen strains had rare mutations at codon 531 (TCG-TGG, TTC, TGC, TAT, and TTT). Twelve strains had rare mutations at codon 516 (GAC-TAC, GTC, and TAC) and one strain contained an insertion of CTT between codons 514 and 515. Seven strains had rare mutations at codon 526 (CAC-TAC, CAG, AAC, CTC, and TGC). Eight strains 
Table 1 Pattern of gene mutations in rpoB gene detected by Genotype MTBDRplus and DNA sequencing of the rpoB gene for pattern of resistance in MTB strains

\begin{tabular}{|c|c|c|c|c|c|}
\hline \multirow[b]{2}{*}{ Gene } & \multirow[b]{2}{*}{ Codons } & \multirow[b]{2}{*}{$\begin{array}{l}\text { Number by drug resistance category } \\
\text { and } r p o B \text { gene loci }\end{array}$} & \multicolumn{3}{|c|}{ Resistance classification } \\
\hline & & & Gene region & $\begin{array}{l}\text { Absent wild } \\
\text { type probe }\end{array}$ & DNA sequencing results \\
\hline \multirow[t]{20}{*}{$r p o B$} & $531(14)$ & $9,1,1,1$ & $531-533$ & WT ${ }^{a}$ & $\begin{array}{l}\text { TCG-TGG (Ser-Trp), TCG-TGC (Ser-Cys), TCG-TAT } \\
\text { (Ser-Tyr), TCG-TTT' (Ser-Phe) }\end{array}$ \\
\hline & $531 \& 526$ & 1 & $531-533$ & WT $8^{\mathrm{a}}$ & TCG-TGG (Ser-Trp) \& CAC-TAC (His-Tyr) \\
\hline & $531 \& 605$ & 1 & - & - & TCG-TTC (Ser-Phe) \& TAC-GAC (Tyr-Asp) \\
\hline & $526(5)$ & 1,1 & $525-530$ & WT7 & CAC-TGC (His-Cys), CAC-AAC (His-Asp) \\
\hline & $\begin{array}{l}526 \\
506 \& 531\end{array}$ & 1 & $525-530$ & - & $\begin{array}{l}\text { CAC-CTC (His-Leu), TTC-TTA (Phe-Leu) \& TCG- } \\
\text { TGG (Ser-Trp) }\end{array}$ \\
\hline & $526 \& 528$ & 1 & - & $W T 7^{a}$ & CAC-CTC (His-Leu) \& CGC-TGC (Arg-Cys) \\
\hline & $526 \& 506$ & 1 & - & WT7 & CAC-CTC (His-Leu) \& TTC-TTA (Phe-Leu) \\
\hline & $516(12)$ & 1 & $513-517$ & $W T 3^{a}$ & Ins CTT (Leu) b/w 514-515 \\
\hline & - & 1 & & WT3 & GAC-TAC (Asp-Tyr) \\
\hline & - & 3,6 & $\begin{array}{l}513-517 \& 516- \\
519\end{array}$ & WT3\&4 & GAC-GTC (Asp-Val), GAC-TAC (Asp-Tyr) \\
\hline & $509 \& 516$ & 1 & $\begin{array}{l}506-509,513-517 \\
\& 516-519\end{array}$ & WT $1,3 \& 4$ & AGC-ATC (Glu-His), GAC-TAC (Asp-Tyr) \\
\hline & 516 & 1 & - & $W T 4^{a}$ & GAC-GTC (Asp-Val) \\
\hline & $513(4)$ & $2,1,2$ & & WT3\&4 & $\begin{array}{l}\text { CAA-CCA (Gln-Pro), CAA-GAA (Gln-Glu), CAA- } \\
\text { GTA (Gln-Val) }\end{array}$ \\
\hline & \multirow[t]{2}{*}{$513 \& 526$} & 1,1 & - & WT3\&4 & CAA-CTA (Gln-Leu) \& CAC-CAG (His-Gln) \\
\hline & & 1 & - & WT3\&4 & Ins CTT (Leu) at 513-514 \\
\hline & $515 \& 572$ & 1 & $513-517$ & WT3 ${ }^{\mathrm{a}}$ & ATG-CTG (Met-Leu) \& ATC-TTC (lle-Phe) \\
\hline & $511(3)$ & $1,2,1$ & $510-513$ & WT2 & $\begin{array}{l}\text { CTG-CCG (Leu-Pro), Ins CCG (Pro) at 511-513, } \\
\text { Ins GAG (Glu) at 511-512 }\end{array}$ \\
\hline & $518(3)$ & 2 & $518-522$ & WT5 & AAC-GAC (Asn-Asp) \\
\hline & - & 1 & $\begin{array}{l}518-522 \& 522- \\
525\end{array}$ & WT5\&6 & Del AAC (Thr) \\
\hline & 518 & 1 & $516-520$ & WT4 & AAC-GAC (Asn-Asp) \\
\hline
\end{tabular}

indeterminate results

Bold columns showing new mutations

had rare mutations at codon 513 (CAA-CCA, GAA, GTA, and CTA). One strain contained mutation at codon 515 (ATG-CTG), one strain contained mutation at codon 511 (CTG-CCG), two strains had insertion of CCG between codons 511 and 513 and one strain had insertion of GAG between codons 511 and 512. Two strains had mutations at codon 518 (AAC-GAC) and one strain had a deletion of ATA (Fig. 2).

Two strains contained mutation from TTC to TTA at codon 506, one strain contained mutation from CGC to TGC at codon 528, one strain had a mutation from CAC to CAG at codon 510, one strain had a mutation from AGC to ATC and one strain had a mutation at codon 533 from CTG-CCG (Table 1). Multiple sequence alignment result of $22 \mathrm{MTB}$ strains that harbor most common and rare mutations in the $r p o B$ gene have shown in supplementary file-1.
Two new mutations (TAC to GAC at codon 605 and ATC to TTC at codon 572) outside the 81-bp hot-spot region was also seen in two strains together double or triple mutations at different codons (Fig. 4). Ten new mutations were also recognized in this study. A mutation from TCG (Ser) to TTC (Phe) at codon 531, a mutation from CAC (His) to TGC (Cys) and a mutation from CAC (His) to CTC (Leu) at codon 526, a mutation at codon 513 from CAA (Gln) to GTA (Val), a mutation at codon 515 from ATG (Met) to CTG (Leu), insertion of CCG (Pro) between codon 511 and 513 and one insertion of GAG (Glu) between codon 511 and 512 (Table 1).

\section{Discussion}

Rapid detection of genes associated with rifampicinresistant in $M$. tuberculosis strains is a key challenge for 


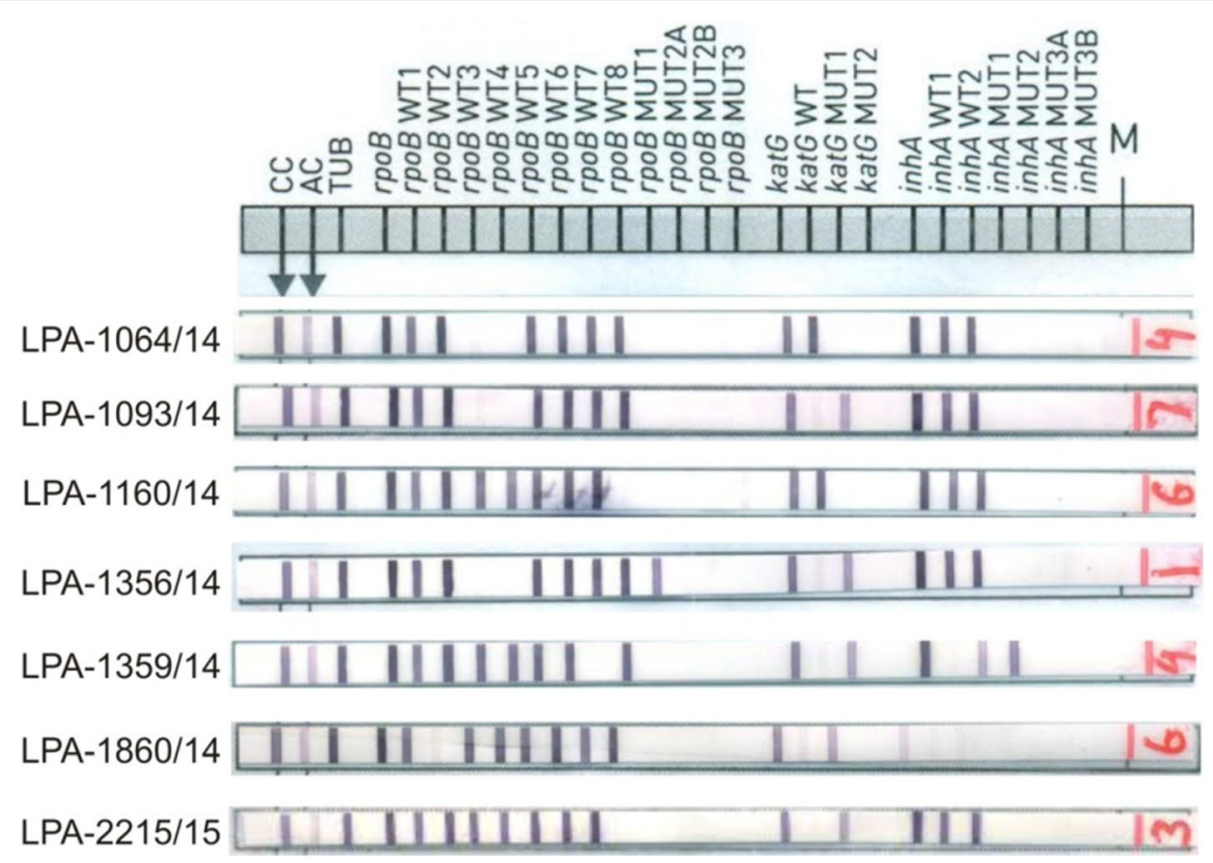

Fig. 1 Strips of hybridization patterns of rifampicin resistance in MTBDRplus assay

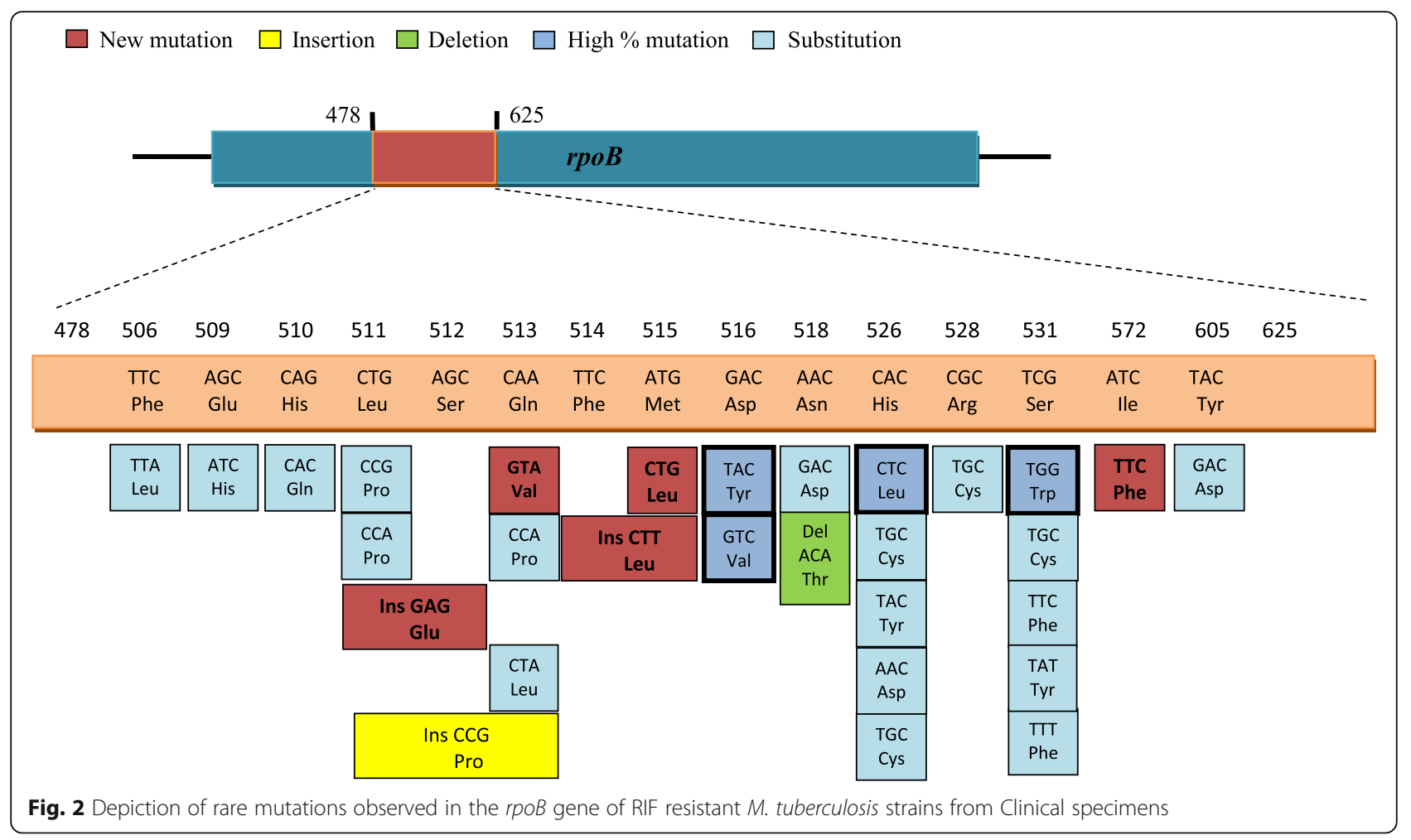


the treatment of tuberculosis. Besides, during this time geographical observation of rising MTB drug resistance would make possible more appropriate antibiotic treatment approaches. At present, the GenoType MTBDRplus, molecular methods offer limited detection, mainly when a novel or rare amino acid substitutions are inside known drug resistance regions. Genotypic test like GenoType ${ }^{\circ}$ MTBDRplus assay has a disadvantage of any possibility of silent mutation, i.e. mutations which do not lead to change in amino acid hence not extending to phenotypic drug resistance. Therefore we have used the DNA sequencing method for the detection of rare or uncommon mutations. In addition, we don't know if the new mutations detected are associated or not with RIF-resistance as drug susceptibility testing was not performed in this study.

Various studies have shown that resistance to INH is very common in high-TB-burden countries, and the isolate may not be resistant to RIF [15]. Conversely, if the isolate is RIF resistant, it is more likely that it is also INH resistant, thus making RIF resistance a surrogate marker for the identification of MDR-TB [16].

Seifert et al have studied that, for any gene region, the absence of the WT probe hybridization most often indicated a failure of MUT probe hybridization, rather than the presence of novel or rare mutations [17]. But in this study molecular analysis of the rpoB gene of $M$. tuberculosis clinical strains was carried out and rare and new mutations were identified by the DNA sequencing method. Some rare mutations at codon 531 (Ser to Trp/ $\mathrm{Cys} / \mathrm{Phe} / \mathrm{Tyr}$ ) were found in the rpoB gene of $32 \%$ strains through sequencing of RIF-resistant strains which is a rare mutation $[18,19]$. Fifteen percent of the strains had the mutation at codon 526 (CTC, TAC, TGC, AAC) that resulted in the conversion of four amino acids (Leu, Tyr, Cys, and Asp); Twenty-one percent of the strains possessed the mutation at codon 516 (GAC to TAC and GTC) that resulted in the conversion of Asp to Tyr and Val respectively, which is in line with previous work [14, 20-22]. Interestingly, a rare mutation at codon 533 (Leu to Pro) was also found in RIF-resistant strains by sequencing analysis, as reported earlier in a few studies [20, 21, 23-25].

New mutations reported in this study include mutation from Arg-Cys at codon 528, Asn-Asp at codon 518, Phe-Leu at codon 506, Leu-Pro at codon 511, Gln-Val/ Glu/Pro/Leu at codon 513 and Gln-His at codon 510. Despite a large number of mutations already reported in other studies, the evidence of new mutations in this study indicates that mutations continue to arise, possibly due to the ability of $M$. tuberculosis to adapt drug exposure.

The rроB mutation not detected by the GenoType MDBDRplus assay was a deletion at codon 518 of the rpo $B$ gene. This region is situated between two probes (WT 4 and 5) and, thus, can be missed due to overlap between these probes. It has been previously reported that deletion at rроB 518 codon missed by another line probe test i.e. the Inno-LiPA Rif.TB. Other Asian countries have also been reported the deletion at 518 [26]. We also found two novel mutations outside the rifampicin-resistant determining region (RRDR) at codon 506 (Phe-Leu) and codon 572 (Ile-Phe). Some novel mutations found inside the RRDR, i.e. 3nucleotide insertions (Leu-514-515, Pro-511-513and Glu-511-512), which are not reported even globally.

In this study, $28 \%$ of the strains possess mutation at codon 513 and 516 in the $r p o B$ region. This region of the $\operatorname{rpo} B$ gene is situated between two probes (WT 3 and 4) and, thus, can be missed due to their overlap. These codons can be added as common mutations in Genotype MTBDRplus for detection of rifampicin resistance detection in Mycobacterium tuberculosis strains, which increases the sensitivity and specificity of this assay for rifampicin resistance detection. In this study, MUT probes that most commonly failed to hybridize were rpoBMUT3 531TTG, due to the absence of WT8 probe and 516GAC and 513CAA mutation due to absence of WT3\&4 probes. This may indicate the need for continued assay optimization over the inclusion of novel MUT probes in GenoType MDBDRplus assay.

The GenoType MDBDRplus assay can observed the mutations in the rpoB gene i.e. Ser-531-Leu, His-526Tyr, His- 526-Asp, and Asp-516-Val, which is the four most frequent mutations in the $r p o B$ gene, while this assay indicates only the presence of a genetic alteration for other mutations. Nevertheless, this study and old studies proposed that the frequencies of specific mutations are dissimilar in different countries; hence, additional studies are essential for how to amend the accurate diagnosis of RIF-resistant $M$. tuberculosis infections using the GenoType MDBDRplus assay.

The limitations of the study are; 1 - Phenotypic drug resistance testing (liquid culture or solid culture) was not performed. So the performance of GenoType ${ }^{\circ}$ MTBDRplus was not assessed as compared to the culture method. 2- The lineage of the isolates studied is not known. 3- Sample size of drug resistance isolates are small however it can be considered as a valid preliminary study. 4- Genexpert was not included in the study.

\section{Conclusions}

The absence of wild type probe hybridization without mutation probe hybridization in Genotype MTBDRplus assay was primarily the result of the failure of mutation probe hybridization and it results in new or rare mutations using DNA sequencing. Additional probes are necessary to be included in the MTBDRplus assay to 


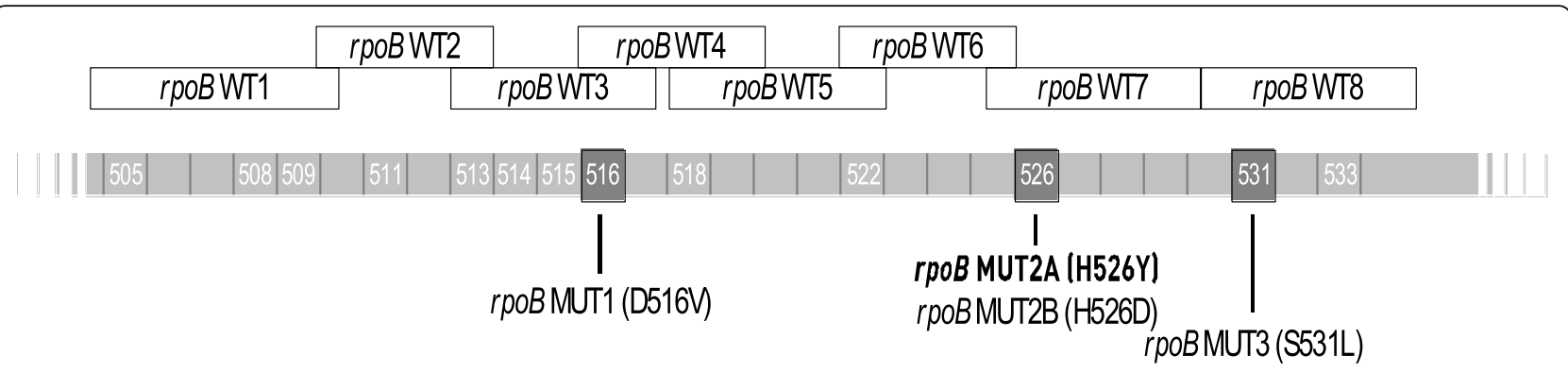

Fig. 3 The description of the probes of the MTBDRplus kit on the rpoB sequence in Mycobacterium tuberculosis

improve the detection of rifampicin-resistant Mycobacterium tuberculosis strains.

\section{Methods \\ Setting}

The study was performed at the Department of Microbiology, Institute of Medical Sciences, Banaras Hindu University, Varanasi, India from February 2015 to May 2016. The Mycobacteriology Laboratory is accredited by the National Accreditation Board for Testing and Calibration Laboratories (NABL) for the performance of the MTBDR plus assay and Drug susceptibility test by MGIT and solid method.

\section{Study design and ethics statement}

This study was carried out to find out the diagnostic performance of the GenoType MTBDRplus assay in sputum samples in comparison with DNA sequencing methodologies.

The study was ethically approved by the ethical committee of the Institute of Medical Sciences, Banaras Hindu University, Varanasi, India.
Specimen processing and rifampicin drug resistance

A total of 150 sputum samples obtained from 150 patients were used in this study. The samples were processed using the $\mathrm{N}$-acetyl-L-cysteine-sodium hydroxide (NALC-NaOH) method of digestion and decontamination [27]. After digestion and decontamination, specimens were neutralized and centrifuged at 3000x $g$ for 15 min.

\section{LPA MTBDRplus assay (Hain Lifescience, Nehren, Germany)}

The LPA MTBDRplus assay was performed on each sample according to the manufacturer's instructions [28-30]. MTBDRplus assay utilizes polymerase chain reaction (PCR) amplification followed by reverse hybridization to specific, immobilized oligonucleotide probes to detect either Mycobacterium tuberculosis (MTB) wild type sequences or mutations associated with RIF and INH resistance.

MTBDRplus assay was performed on decontaminated sputum sediment. For, DNA extraction, $500 \mu \mathrm{l}$ of decontaminated sediment was centrifuged and resuspended with $100 \mu \mathrm{l}$ sterile molecular grade water. Bacterial pellets were subjected to chemical lysis using the Genolyse

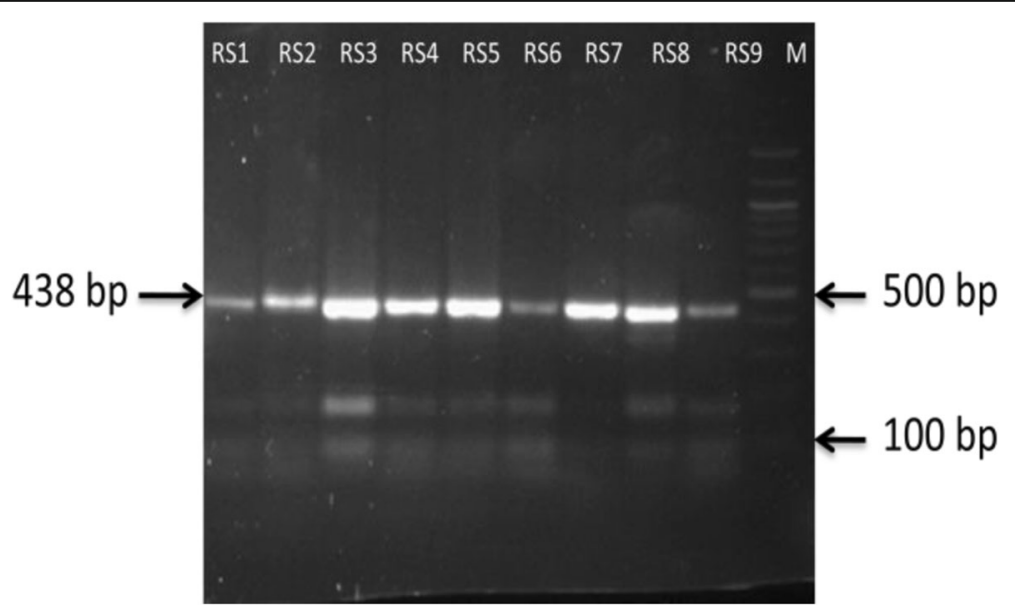

Fig. 4 Electrophoresis gel of PCR results for sequencing of rpoB gene in Mycobacterium tuberculosis 
kit. Multiplex PCR was executed by HotStar Taq DNA polymerase $250 \mathrm{U}$ (Qiagen GmBH, Hilden, Germany), for sediment with 40 amplification cycles and for cultured specimens with 30 cycles. The following reaction conditions were used: denaturation at $95^{\circ} \mathrm{C}$ for $5 \mathrm{~min}$, followed by 10 cycles of $30 \mathrm{~s}$ at $95^{\circ} \mathrm{C}$ and $2 \mathrm{~min}$ at $58^{\circ} \mathrm{C}$, followed by 20 additional cycles of $25 \mathrm{~s}$ at $95^{\circ} \mathrm{C}, 40 \mathrm{~s}$ at $53^{\circ} \mathrm{C}$, and $40 \mathrm{~s}$ at $70^{\circ} \mathrm{C}$, ending with a final extension step of $8 \mathrm{~min}$ at $70^{\circ} \mathrm{C}$. According to the manufacturer's instructions hybridization and detection were carried out with a TwinCubator (Hain Lifescience $\mathrm{GmbH}$ ) semiautomated washing and shaking device and using the reagents provided with the kit.

For the detection of RIF resistance, the MTBDRplus assay strip contains 8 rpoB wild type probes (including codons 505 to 533); D516V, D526Y, H526D, and S531L, the four mutant probes in the $r p o B$ gene that ranges from 505 to 533 codon (Fig. 3).

The interpretation of MTBDRplus assay has been done by follow these methods. If on the test strip one or more MUT probes hybridize and one or more WT probes fail to hybridize or if one or more WT probes fail to hybridize (without MUT probe hybridization) then that MTB strains are resistant. The absence of one or more WT probes hybridization and failure of the MUT probe hybridization provide an indirect method to identify novel or rare mutations located in those regions covered by the specific WT probes [31].

\section{DNA sequencing}

\section{Primer design}

Novel PCR primer was designed for the amplification of the $r p o B$ gene. Primer pairs for amplification of the $r p o B$ gene were intended using the genome sequence of $M$. tuberculosis H37Rv strain (GenBank accession no. NC 000962) as reference. Melting temperature, secondary structure formation, and potential primer-dimer formation were find out using LaserGene 9.1 (DNAStar, Madison, WI) and Primer Express 3.0 (Life Technologies, Foster City, CA).

\section{Sequencing of $r p o B$ gene}

DNA sequencing was performed on all clinical specimens found to be non-interpretable on LPA MTBDRplus assay by Sanger sequencing. The regions of $r р о B$ associated with Rif $^{\mathrm{r}}$ were sequenced after amplification by PCR. The forward RSF (5'-GATGAC CACCCAGGACGTGGAG-3') and reverse RSR (5'TCGATCGGCGAATTGGCCTGTG-3') primers used for both PCR and sequencing to amplify a 438-bp fragment of the rрoB gene containing the 81-bp hypervariable region (Fig. 4). The $25 \mu \mathrm{l} \mathrm{PCR}$ reactions were performed with $5 \mu \mathrm{l} 10 \mathrm{X}$ Q5 reaction buffer (New England BioLabs), $1 \mu \mathrm{l} 200 \mu \mathrm{M}$ of each dNTP,
Q5 hot start Taq DNA polymerase (New England BioLabs), $5 \mu \mathrm{l}$ Q5 GC enhancer (New England BioLabs), $10 \mu \mathrm{l}$ of DNA from the specimen and $10 \mathrm{pmol}$ of each primer (GeNei, Banglore, India) and added Milli Q to create a total volume of $25 \mu \mathrm{l}$.

\section{Reaction condition}

Each reaction was initiated at $98^{\circ} \mathrm{C}$ for $30 \mathrm{~s}$, run $35 \mathrm{cy}$ cles of $\left(98^{\circ} \mathrm{C}\right.$ for $10 \mathrm{~s}, 66^{\circ} \mathrm{C}$ for $25 \mathrm{~s}, 72^{\circ} \mathrm{C}$ for $\left.30 \mathrm{~s}\right)$ and finally elongated at $72{ }^{\circ} \mathrm{C}$ for $2 \mathrm{~min}$.

\section{Visualization of PCR product}

The PCR product was confirmed on an agarose gel to be approximately $438 \mathrm{bp}$.

\section{Sequencing and assembly}

All amplicons were subjected to DNA sequencing (Sci Genome, Cochin, Kerala, India). The obtained sequences were assembled manually, and polymorphisms detection was achieved by comparison with the available sequences for the rpoB gene of $M$. tuberculosis H37Rv sequence. The new mutations were analyzed using clustal Omega programs. The genome sequencing has been deposited at DDBJ/EMBL/GenBank. These are under the processing (Supplimetary material-1).

\section{Supplementary information}

Supplementary information accompanies this paper at https://doi.org/10. 1186/s12866-020-01967-5.

\section{Additional file 1}

\section{Abbreviations}

MTBC: Mycobacterium tuberculosis complex; WT: Wild type; HIV: Human immunodeficiency virus; LPA: Line Probe Assay; INH: Isoniazid; RIF: Rifampicin; MDR-TB: Multidrug resistant-tuberculosis; PCR: Polymerase chain reaction; RRDR: Rifampicin-resistant determining region

\section{Acknowledgments}

We would like to express our sincere thanks to the Head, Department of Microbiology, Institute of Medical Sciences, and to the patients, staff, and management of the Sir Suderlal Hospital, Banaras Hindu University, Varanasi.

\section{Authors' contributions}

1) PS, GNS, RT, MNM, SA have made substantial contributions to conception and design, or acquisition of data, or analysis and interpretation of data; 2) PS, SA has been involved in drafting the manuscript or revising it critically for important intellectual content; and 3) PS, SA, GNS, RT, MNM have given final approval of the version to be published.

\section{Funding}

This project was funded by the Department of Science and Technology, New Delhi (Grant No. DST/INSPIRE Fellowship/2011). The funders had no role in study design, data collection, and analysis, decision to publish, or preparation of the manuscript.

Availability of data and materials

The datasets used and/or analyzed during the current study are available from the corresponding author on reasonable request. 


\section{Ethics approval and consent to participate}

The study was ethically approved by the ethical committee of the Institute of Medical Sciences, Banaras Hindu University, Varanasi, India. Consent to participate is not applicable.

\section{Consent for publication}

Not applicable.

\section{Competing interests}

All the authors declare that they have no competing interests in this study.

\section{Author details}

'Department of Microbiology, Institute of Medical Sciences, Banaras Hindu University, Varanasi 221 005, India. ${ }^{2}$ Department of Respiratory Diseases, Institute of Medical Sciences, Banaras Hindu University, Varanasi, Uttar Pradesh 221005, India. ${ }^{3}$ CSIR-Central Institute of Medicinal and Aromatic Plants, Lucknow 226015, India.

Received: 9 December 2019 Accepted: 3 September 2020

Published online: 16 September 2020

\section{References}

1. World Health Organization, editor. Global tuberculosis report. World Health Organization (ed.) Appia. Geneva: WHO Press; 2017. http://www.who.int/tb/ publications/global_report/en.

2. World Health Organization. Global tuberculosis control: surveillance, planning, financing. WHO report 2009. WHO/ HTM/TB/2009.411. Geneva: WHO; 2009 .

3. Espinal MA, Kim SJ, Suarez PG, et al. Standard short-course chemotherapy for drug-resistant tuberculosis: treatment outcomes in 6 countries. JAMA. 2000;283:2537-45

4. World Health Organization. Molecular line probe assays for rapid screening of patients at risk of multidrug-resistant tuberculosis (MDR-TB). Geneva: World Health Organization; 2008.

5. Pai M, Schito M. Tuberculosis diagnostics in 2015: landscape, priorities, needs, and prospects. J Infect Dis. 2015;211:S21-8.

6. World Health Organization. WHO policy statement: molecular line-probe assays for rapid screening of patients at risk of multidrug-resistant tuberculosis. Geneva: WHO; 2008. http://www.who.int/tb/features_archive/ policy statement.pdf Accessed December 2015.

7. Madhuri K, Deshpande S, Dharmashale S, Bharadwaj R. Utility of line probe assay for the early detection of multidrugresistant pulmonary tuberculosis. Global Infect Dis. 2015;7:6065.

8. Luetkemeyer AF, Kendall MA, Wu X, Lourenço MC, Jentsch U, Swindells S, Qasba SS, Sanchez J, Havlir DV, Grinsztejn B, Sanne IM, Firnhaber C, Adult AIDS. Clinical trials group A5255 study team. Evaluation of two line probe assays for rapid detection of Mycobacterium tuberculosis, tuberculosis (TB) drug resistance, and non-TB mycobacteria in HIV-infected individuals with suspected TB. J Clin Microbiol. 2013;52(4):1052-9.

9. Heysell SK, Houpt ER. The future of molecular diagnostics for drug-resistant tuberculosis; 2012.

10. Yam WC, Tam CM, Leung CC, Tong HL, Chan KH, Leung ET, Wong KC, Yew WW, Seto WH, Yuen KY, Ho PL. Direct detection of rifampin-resistant mycobacterium tuberculosis in respiratory specimens by PCR-DNA sequencing. J Clin Microbiol. 2004;42:4438-43.

11. Helb D, Jones M, Story E, Boehme C, Wallace E, Ho K, et al. Rapid detection of Mycobacterium tuberculosis and rifampin resistance by use of on-demand near-patient technology. J Clin Microbiol. 2010;48(1):229-37.

12. Chen L, Gan X, Li N, Wang J, Li K, Zhang H. rpoB gene mutation profile in rifampicin-resistant Mycobacterium tuberculosis clinical isolates from Guizhou, one of the highest incidence rate regions in China. J Antimicrob Chemother. 2010:1299-301. https://doi.org/10.1093/jac/dkq102.

13. Thakur C, Kumar V, Gupta AK. Detecting mutation pattern of drug resistant mycobacterium tuberculosis isolates in Himanchal Pradesh using genotype MTBDR plus assay. Indian J Med Microbiol. 2015;33(4):547-53.

14. Rahman A, Sahrin M, Afrin S, Earley K, Ahmed S, Rahman SM, \& Banu S. Comparison of Xpert MTB/RIF Assay and GenoType MTBDRplus DNA Probes for Detection of Mutations Associated with Rifampicin Resistance in Mycobacterium tuberculosis. PLoS One 2016; 11(4): e0152694. doi: 10. 0151371/journal.pone.0152694. eCollection 0152016.
15. Kumar P, Balooni V, Sharma BK, Kapil V, Sachdeva KS, Singh S. High degree of multidrug resistance and hetero-resistance in pulmonary TB patients from Punjab state of India. Tuberculosis. 2014;94:73-80.

16. Somoskovi A, Parsons LM, Salfinger M. The molecular basis of resistance to isoniazid, rifampin, and pyrazinamide in Mycobacterium tuberculosis. Respir Res. 2001;2:164-8.

17. Seifert M, Georghiou SB, Catanzaro D, Rodrigues C, Crudu V, Victor TC, Garfein RS, Catanzaro A, Rodwella TC. MTBDRplus and MTBDRsl assays: the absence of wild type probe hybridization and implications for the detection of drug-resistant tuberculosis. J Clin Microbiol. 2016. https://doi.org/10.1128/ JCM.02505-15.

18. Jenkins C, Claxton AP, Shorten RJ, McHugh TD, Gillespie SH. Rifampicin resistance in tuberculosis outbreak, London, England. Emerg Infect Dis. 2005;11:931-4

19. Faroogi JQ, Khan E, Alam SMZ, Ali A, Hasan Z, Hasan R. Line probe assay for detection of rifampicin and isoniazid resistant tuberculosis in Pakistan. JPMA. 2012;62:767.

20. Qazi O, Rahman H, Tahir Z, Qasim M, Khan S. Mutation pattern in rifampicin resistance determining region of $r p o B$ gene in multidrug-resistant Mycobacterium tuberculosis isolates from Pakistan. Int J Mycobacteriol. 2014; 3:173-7.

21. Qian G, Yan Y, Ling ZY, Qin ZX, Guang LZ. Rapid detection of rifampinresistant clinical isolates of Mycobacterium tuberculosis by reverse dot blot hybridization. Biomed Environ Sci. 2015;28(1):25-35.

22. Sharma S, Madan M. Detection of Mutations in rpoB Gene of Clinically Isolated M. tuberculosis by DNA Sequencing. Detection of Mutations in rpob Gene of Clinically Isolated M. tuberculosis by DNA Sequencing. J Mycobac Dis. 2014;4:156.

23. Ma X, Wang H, Deng Y, Liu Z, Xu Y, Pan X, Musser JM, Graviss EA. rpoB gene mutations and molecular characterization of rifampinresistant Mycobacterium tuberculosis isolates from Shandong Province, China. J Clin Microbiol. 2006;44:3409-12.

24. Cavusoglu C, Hilmioglu S, Guneri S, Bilgic A. Characterization of rpoB mutations in rifampin-resistant clinical isolates of Mycobacterium tuberculosis from Turkey by DNA sequencing and line probe assay. J Clin Microbiol. 2002:40:4435-8.

25. Rufai SB, Kumar P, Singh A, Prajapati S, Balooni V. Comparison of Xpert MTB/ RIF with line probe assay for detection of rifampin- Monoresistant Mycobacterium tuberculosis. J Clin Microbiol. 2014;52(6):1846-52

26. Prammananan T, Cheunoy W, Taechamahapun D, Yorsangsukkamol J, Phunpruch S, Phdarat P, et al. Distribution of rpoB mutations among multidrugresistant mycobacterium tuberculosis (MDRTB) strains from Thailand and development of a rapid method for mutation detection. Clin Microbiol Infect. 2008:14:446-53.

27. Kent PT, GPW K. Public Health Mycobacteriology. A guide for the level III Laboratory. Atlanta: Centers for Disease Control; 1985. p. 21-44.

28. Hain Lifescience GmbH. GenoTypeMTBDRplus, version 2.0 product insert. Nehren, Germany.

29. Brossier F, Veziris N, Truffot-Pernot C, Jarlier V, Sougakoff W. Performance of the genotype MTBDR line probe assay for detection of resistance to rifampin and isoniazid in strains of Mycobacterium tuberculosis with lowand high-level resistance. J Clin Microbiol. 2006;44:3659-401 3664.

30. Barnard M, van Pittius NCG, van Helden PD, Bosman M, Coetzee G, Warren RM. The diagnostic performance of the GenoType MTBDRplus version 2 line probe assay is equivalent to that of the Xpert MTB/RIF assay. I Clin Microbiol. 2012;50:3712-6.

31. Lin SY, Desmond EP. Molecular diagnosis of tuberculosis and drug resistance. Clin Lab Med. 2014;34:297-314.

\section{Publisher's Note}

Springer Nature remains neutral with regard to jurisdictional claims in published maps and institutional affiliations. 